\title{
cDNA sequence analysis, gene expression and protein localisation of the inhibin $\alpha$-subunit of Australian brushtail possum (Trichosurus vulpecula)
}

\author{
D Vanmontfort ${ }^{1,2}$, A E Fidler ${ }^{1}$, D A Heath ${ }^{1}$, S B Lawrence ${ }^{1}$, \\ D J Tisdall ${ }^{1}$, P J Greenwood ${ }^{1}$ and K P McNatty ${ }^{1}$ \\ ${ }^{1}$ AgResearch Wallaceville, PO Box 40063, Upper Hutt, New Zealand \\ ${ }^{2}$ Department of Animal Sciences, Catholic University of Leuven, Kardinaal Mercierlaan 92, \\ 3001 Heverlee, Belgium
}

(Requests for offprints should be addressed to D Vanmontfort, Department of Animal Sciences, Catholic University of Leuven, Kardinaal Mercierlaan 92, 3001 Heverlee, Belgium)

\begin{abstract}
An inhibin $\alpha$-subunit cDNA sequence from the Australian brushtail possum (Trichosurus vulpecula) has been identified and analysed. The cDNA includes an open reading frame encoding a predicted precursor protein of 361 amino acids. The predicted protein sequence includes four possible proteolytic cleavage sites, 12 evolutionarily conserved cysteine residues and three potential $\mathrm{N}$-linked glycosylation sites. The mature $\alpha$-subunit is the carboxyl terminal fragment $(\alpha \mathrm{C})$ consisting of 131 amino acids. The full-length precursor protein shows a mean identity with eutherian homologues of $69.8 \%$. The homology is not evenly distributed, with the putative $\alpha \mathrm{C}$ fragment showing the highest level $(79 \cdot 7 \%)$. Using Northern hybridisation, an $\alpha$-subunit transcript of approximately $1.6 \mathrm{~kb}$ was detected in adult possum ovary. Using in situ
\end{abstract}

hybridisation and immunocytochemistry, inhibin $\alpha$-subunit was localised exclusively to the granulosa cell layers of follicles. Hybridisation and immunostaining for the inhibin $\alpha$-subunit were first observed in granulosa cells of primary follicles and the expression continued throughout all stages of follicular growth. Inhibin $\alpha$-subunit mRNA and protein were also detected in cells of the corpus luteum. In summary, results indicate considerable conservation of the structure and possible function of the inhibin $\alpha$-subunit protein since the divergence of the marsupial and eutherian mammalian lineages. The expression data suggest that, in the adult possum, inhibin may have a role in ovarian follicular growth from the primary stage of development.

Fournal of Molecular Endocrinology (1998) 21, 141-152

\section{INTRODUCTION}

The mammalian reproductive cycle is regulated through the actions and interactions of hormones secreted by the hypothalamus, pituitary and gonads (Woodruff et al. 1987). Follicular development and spermatogenesis are dependent primarily on the actions of follicle-stimulating hormone (FSH) and luteinising hormone (Richards et al. 1986, Steinberger 1971). Inhibin, a protein hormone originally purified from ovarian follicular fluid (Ling et al. 1985, Miyamoto et al. 1985, Robertson et al. 1985), has been shown to exert a negative feedback on FSH secretion (Steinberger \& Steinberger 1976, Schwartz \& Channing 1977). In addition to regulating gonadotrophin secretion, inhibin exerts paracrine and autocrine effects within the gonads (Findlay 1993).

Inhibin is a heterodimeric glycoprotein consisting of an $\alpha$-subunit and a $\beta$-subunit, joined by disulphide bridges. Two forms of the inhibin $\beta$-subunit, termed $\beta \mathrm{A}$ and $\beta \mathrm{B}$, have been isolated (Mason et al. 1985); in combination with an $\alpha$-subunit, they form inhibin-A and inhibin-B respectively. In addition, homodimers of the $\beta$-subunits form activin, which enhances pituitary FSH production (Ling et al. 1986). Inhibin is primarily produced by ovarian granulosa cells (Erickson \& Hsueh 1978) and by Sertoli cells of the testis (Steinberger \& Steinberger 1976). Inhibin 
$\alpha$-subunit precursor cDNA sequences for six eutherian mammalian species have been published: porcine (Mason et al. 1985), human (Mayo et al. 1986), bovine (Forage et al. 1986), rat (Esch et al. 1987, Woodruff et al. 1987), murine (Albano et al. 1993) and equine (Yamanouchi et al. 1995). However, comparatively little is known about the structure, function or localisation of inhibins in marsupials.

In the present paper, a cDNA sequence, the gene expression and the protein localisation of the brushtail possum inhibin $\alpha$-subunit are reported.

\section{MATERIALS AND METHODS}

All experiments were performed with approval granted by the Animal Ethics Committee at Wallaceville Animal Research Centre and in accordance with the 1987 Animal Protection (Codes of Ethical Conduct) Regulations of New Zealand.

\section{Reverse transcriptase-PCR}

Adult possums were killed and their ovaries were collected and stored at $-70{ }^{\circ} \mathrm{C}$. Total RNA was extracted using TRIzol Reagent (Gibco BRL, Grand Island, NY, USA) and first-strand cDNA was synthesised using Superscript II reverse transcriptase (Superscript Preamplification System, Gibco BRL). Target cDNA sequences were amplified by PCR. Five microlitres of first-strand cDNA were amplified using $5 \mathrm{U}$ Taq DNA polymerase (Boehringer Mannheim, Mannheim, Germany) in a total volume of $50 \mu$ l containing 20 pmol of each primer and the manufacturer's recommended buffer. PCR was conducted in a thermal cycler (Perkin Elmer Cetus Corporation, Norwalk, CT, USA) with one cycle $\left(94^{\circ} \mathrm{C}\right.$ for $1 \mathrm{~min})$, followed by 35 cycles $\left(94{ }^{\circ} \mathrm{C}\right.$ for $30 \mathrm{~s} ; 60^{\circ} \mathrm{C}$ for $1 \mathrm{~min} ; 72^{\circ} \mathrm{C}$ for $2 \mathrm{~min}$ ) and a final extension at $72{ }^{\circ} \mathrm{C}$ for $7 \mathrm{~min}$. The PCR primers were designed from conserved nucleotide sequences identified by comparison of eutherian inhibin $\alpha$-subunit cDNA sequences (human (Mayo et al. 1986), mouse (Albano et al. 1993), rat (Woodruff et al. 1987), bovine (Forage et al. 1986), porcine (Mason et al. 1985), equine (Yamanouchi et al. 1995)): forward primer 5'-CAGGGAGCTGGTGCTGGCCAA-3' (150-170); reverse primer 5'-AGCCAAGCTCC TGGAAAGAGA-3' (866-886). The positions of the primers are indicated between brackets and correspond to the respective bases of the cDNA sequence (Fig. 1). A single amplification product of the predicted size $(737 \mathrm{bp})$ was produced and corresponded to bases 150-886 of the cDNA sequence (Fig. 1).

To obtain the full-length cDNA sequence, gene specific primers (GSPs) were designed for both 3' and $5^{\prime}$ RACE (rapid amplification of cDNA ends) (Frohman et al. 1988). 3' RACE GSPs: GSP1 5'-TGGTGACACTGCTGGCGATGTC-3' (512533); GSP2 5'-GCTTGCTGCAGCGTCCAT CA-3' (800-819). 5' RACE GSPs: GSP1 5'-CC AGCAGTGTCAC-3' (514-526); GSP2 5'-GT GGACTTCGGCACCCACCTTG-3' (474-495); GSP3 5'-GAGGCCAGTGTGGAACCACAG-3' (451-471). The RACE reaction conditions were as specified by the manufacturer (Gibco BRL).

\section{Cloning and sequencing}

PCR amplification products were electrophoresed through $1 \% \quad(\mathrm{w} / \mathrm{v})$ low melting point agarose gels (SeaPlaque, FMC BioProducts, Rockland, ME, USA), extracted (Qiaquick Gel Extraction Kit, Qiagen, Hilden, Germany), ligated into pGEMTeasy (Promega, Madison, WI, USA) and transformed into competent Escherichia coli DH5 $\alpha$ cells (Hanahan 1985). Plasmids having inserts were identified by restriction enzyme digestion and the insert sequences determined using an ABI 373 DNA sequencer (Applied Biosystems, Foster City, CA, USA). All enzymes were used according to the manufacturer's specifications (Boehinger Mannheim). The full-length cDNA sequence was derived from the original 737-bp fragment and the different $3^{\prime}$ and $5^{\prime}$ RACE pieces.

\section{Northern hybridisation}

Total RNA was extracted from adult possum ovary and liver using TRIzol (Gibco BRL) and $5 \mu \mathrm{g}$ electrophoresed through a $1 \%(\mathrm{w} / \mathrm{v})$ agarose gel in denaturing electrophoresis buffer $(7 \cdot 0 \% \quad(\mathrm{v} / \mathrm{v})$ formaldehyde, $1 \times$ MOPs (20 mM 4-morpholinopropanesulphonic acid $\mathrm{pH} 7 \cdot 0,4 \cdot 8 \mathrm{mM}$ sodium acetate, $1.0 \mathrm{mM}$ EDTA). RNA transcript size was estimated by comparison with a $0 \cdot 24-9 \cdot 5-\mathrm{kb}$ RNA ladder (Gibco BRL) and the positions of $18 \mathrm{~S}$ and $28 \mathrm{~S}$ ribosomal RNA bands. Gels were equilibrated in $20 \times \mathrm{SSC}(3 \mathrm{M}$ sodium chloride, $0 \cdot 3 \mathrm{M}$ sodium citrate, $\mathrm{pH} 7 \cdot 0$ ) and RNA was transferred by capillary action to Hybond $\mathrm{N}$ membranes (Amersham International plc, Little Chalfont, Bucks, UK). A possum inhibin $\alpha$-subunit cDNA clone was radiolabelled $\left(\left[\alpha-{ }^{32} \mathrm{P}\right] \mathrm{dCTP}\right)$ using the Rediprime DNA labelling system (Amersham). The probes and membranes were hybridised in hybridisation buffer $\left(0.5 \mathrm{M} \mathrm{Na}_{2} \mathrm{HPO}_{4}-0.5 \mathrm{M} \mathrm{NaH} \mathrm{PO}_{4}\right.$, $\mathrm{pH} 7 \cdot 2,7 \%(\mathrm{w} / \mathrm{v})$ SDS, $1 \mathrm{mM}$ EDTA, $10 \%(\mathrm{w} / \mathrm{v})$ 


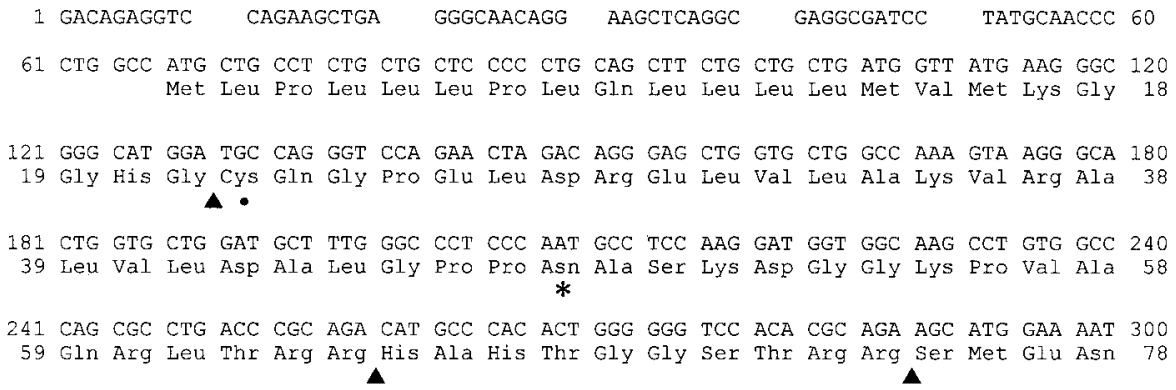

961 CCA GTC CTG TCT CCT GGG GCT GCC CTC ACG CCT TCT CAG CCA CrG CCC CTG GGC CCA GGC 1020 299 Pro Val Leu Ser pro Gly Ala Ala Leu Thr pro Ser Gln Pro Leu Pro Leu Gly Pro Gly 318

1021 TCC CGG CCT TGT TGT GCT GCT ATG CCT AGC ACC ATG AGA CCC CTT CGA GTC CGT ACC ACC 1080 319 Ser Arg pro Cys Cys Ala Ala Met pro Ser Thr Met Arg Pro Leu Arg val Arg Thr Thr 338

1081 TCA GAC GGA GGC TAT TCC TTC AAG TAT GAG ATA GTG CCC AAC CTC CTC ACT CAA CAC TGT 1140 339 Ser Asp Gly Gly Tyr Ser phe Lys Tyr Glu Ile Val Pro Asn Leu Leu Thr Gln His Cys 358

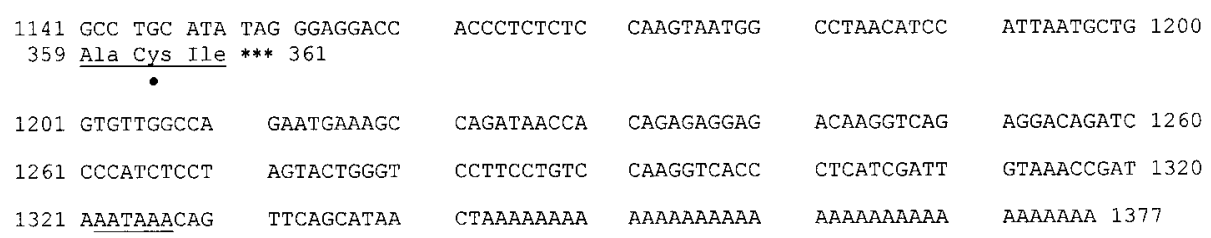

FIGURE 1. Nucleotide (cDNA) and deduced amino acid sequences of possum inhibin $\alpha$-subunit gene. The mature inhibin $\alpha$-subunit $(\alpha \mathrm{C})$ sequence and the consensus polyadenylation signal (AATAAA) are underlined. The positions of potential N-linked glycosylation sites $(*)$, cysteine residues $(\bigcirc)$ and potential proteolytic cleavage sites $(\boldsymbol{\Delta})$ are indicated, as is the termination codon (***) (Genbank Accession Number: AF033340). 
dextran sulphate) (Church \& Gilbert 1984) for $16-20 \mathrm{~h}$ at $55^{\circ} \mathrm{C}$. The hybridised membranes were sequentially washed in $2 \times \mathrm{SSC}-0 \cdot 1 \% \mathrm{SDS}$ ( $10 \mathrm{~min}$ at room temperature), in $2 \times \mathrm{SSC}-0 \cdot 1 \%$ SDS $\left(30 \mathrm{~min}\right.$ at $\left.65^{\circ} \mathrm{C}\right)$ and finally in $0.1 \times \mathrm{SSC}-$ $0.5 \% \operatorname{SDS}\left(15 \mathrm{~min}\right.$ at $\left.55^{\circ} \mathrm{C}\right)$ before autoradiography at $-70{ }^{\circ} \mathrm{C}$ with an intensifying screen.

\section{In situ hybridisation}

The in situ hybridisation methodology has been described previously ('Tisdall et al. 1994). Radiolabelled $\left(\left[\alpha-{ }^{33} \mathrm{P}\right] \mathrm{UTP}\right)$ RNA probes were synthesised from a 737-bp $\alpha$-inhibin cDNA cloned into pGEMTeasy (Riboprobe Gemini system, Promega).

Ovaries from seven adult possums were fixed in $4 \%(\mathrm{w} / \mathrm{v})$ phosphate-buffered paraformaldehyde and embedded in paraffin. Sections $5 \mu \mathrm{m}$ thick were cut and transferred to Superfrost-Plus glass slides (Erie Scientific, Portsmouth, NH, USA), deparaffinised in xylene and hydrated through an alcohol series to water. Sections were immersed in $0.2 \mathrm{M} \mathrm{HCl}$ ( $20 \mathrm{~min}$, room temperature) and washed in $2 \times \mathrm{SSC}$ for $30 \mathrm{~min}$. The sections were digested with proteinase $\mathrm{K}\left(2 \mu \mathrm{g} / \mathrm{ml}\right.$, Boehringer Mannheim) at $37^{\circ} \mathrm{C}$ for $5 \mathrm{~min}$, immersed in $0.1 \mathrm{M}$ triethanolamine $\mathrm{pH} 8 \cdot 0$, $0 \cdot 25 \%(\mathrm{v} / \mathrm{v})$ acetic anhydride (twice for $5 \mathrm{~min}$, room temperature) and then washed in $2 \times \mathrm{SSC}$ for $5 \mathrm{~min}$ at room temperature before dehydration through an alcohol series to absolute ethanol.

Hybridisation was performed in $50 \%(\mathrm{v} / \mathrm{v})$ formamide, $0 \cdot 3 \mathrm{M} \mathrm{NaCl}, 10 \mathrm{mM}$ Tris- $\mathrm{HCl} \mathrm{pH} 6 \cdot 8$, $10 \mathrm{mM}$ sodium phosphate $\mathrm{pH} 6 \cdot 8,5 \mathrm{mM}$ EDTA $\mathrm{pH} 8 \cdot 0,1 \times$ Denhardt's solution $(0 \cdot 02 \%(\mathrm{w} / \mathrm{v})$ each of BSA, Ficoll and polyvinyl pyrrolidone), 10\% (w/v) dextran sulphate, $50 \mathrm{mM}$ dithiothreitol, $1 \mathrm{mg} / \mathrm{ml}$ tRNA and approximately $2 \times 10^{5}$ c.p.m. $/ \mu \mathrm{l}$ ${ }^{33} \mathrm{P}$-labelled sense or antisense riboprobe at $55{ }^{\circ} \mathrm{C}$ for $18 \mathrm{~h}$. After hybridisation, the slides were washed sequentially in $5 \times \operatorname{SSC}\left(50{ }^{\circ} \mathrm{C}\right.$ for $15 \mathrm{~min}$, twice); $2 \times \mathrm{SSC} / 50 \%(\mathrm{v} / \mathrm{v})$ formamide $\left(65^{\circ} \mathrm{C}\right.$ for $15 \mathrm{~min}$, twice) and $2 \times \mathrm{SSC}\left(37^{\circ} \mathrm{C}\right.$ for $5 \mathrm{~min}$, four times). The sections were incubated with RNase A (Boehringer Mannheim) $(20 \mu \mathrm{g} / \mathrm{ml}$ in $0.4 \mathrm{M} \mathrm{NaCl}$, $10 \mathrm{mM}$ Tris- $\mathrm{HCl} \mathrm{pH} 7 \cdot 5,5 \mathrm{mM} \mathrm{EDTA})$ at $37^{\circ} \mathrm{C}$ for $30 \mathrm{~min}$ and then sequentially washed in $2 \times$ $\mathrm{SSC} / 50 \%(\mathrm{v} / \mathrm{v})$ formamide $\left(65^{\circ} \mathrm{C}\right.$ for $\left.30 \mathrm{~min}\right)$, $2 \times \operatorname{SSC}\left(37^{\circ} \mathrm{C}\right.$ for $\left.15 \mathrm{~min}\right)$ and $0.2 \times \operatorname{SSC}\left(37^{\circ} \mathrm{C}\right.$ for $15 \mathrm{~min})$. The slides were dehydrated through an alcohol series, air dried, coated with autoradiographic emulsion (LM-1 emulsion; Amersham) and exposed at $4{ }^{\circ} \mathrm{C}$ for ten days. The slides were developed (D19 developer; Kodak, Rochester, NY, USA) and fixed photographically to produce visible silver grains over the sites of hybridisation. The tissue sections were stained with haematoxylin and photographed under both light- and dark-field illumination on an Olympus $\mathrm{BH}-2$ microscope. Hybridisation of duplicate sections with a ${ }^{33} \mathrm{P}$ labelled sense riboprobe was used as a negative control.

\section{Immunohistochemistry}

Paraffin-embedded sections were deparaffinised with xylene and rehydrated through an alcohol series to water. Endogenous peroxidase activity was quenched with exposure to $3 \%(\mathrm{v} / \mathrm{v})$ hydrogen peroxide in methanol for $30 \mathrm{~min}$. After antigen retrieval by heating the sections in a pressure cooker containing $0.01 \mathrm{M}$ citrate buffer ( $\mathrm{pH} 6.0$ ) for $1 \mathrm{~min}$, the sections were washed in Tris- $\mathrm{HCl}$ buffer (TBS; $0.5 \mathrm{M}$ Tris(hydroxymethyl)methylamine, $0.9 \%(\mathrm{w} / \mathrm{v}) \mathrm{NaCl}$; pH 7.6) three times for $10 \mathrm{~min}$. Sections were then incubated with non-immune rabbit serum (diluted $1: 5$ in TBS) for $30 \mathrm{~min}$ to reduce non-specific immunostaining. Mouse antiinhibin $\alpha$-subunit (Serotec, Oxford, UK; clone R1; diluted $1: 100$ in $\mathrm{TBS}+0 \cdot 1 \% \quad(\mathrm{w} / \mathrm{v})$ BSA) was applied to the sections and incubated overnight at $4{ }^{\circ} \mathrm{C}$ in a humid chamber. All other incubations and washes were performed at room temperature. The sections were then washed three times for $10 \mathrm{~min}$ in TBS and incubated for $30 \mathrm{~min}$ with the secondary antibody, biotinylated rabbit anti-mouse $\operatorname{IgG}$ (Dakopatts, Dako Corporation, Carpintria, CA, USA) diluted $1: 500$ in TBS containing $0 \cdot 1 \%(\mathrm{w} / \mathrm{v})$ $\mathrm{BSA}$ and $1 \%(\mathrm{v} / \mathrm{v})$ non-immune possum serum.

After the incubation with the primary antibody, all sections were washed three times for $10 \mathrm{~min}$ in TBS and incubated with an avidin-biotinylated horseradish peroxidase complex (Dakopatts), following the manufacturer's instructions, for $30 \mathrm{~min}$. Subsequently, the sections were given three 10-min washes in TBS and the signal was enhanced by use of a tyramide signal amplification kit (NEN Life Science Products, Boston, MA, USA), following the manufacturer's instructions. The immunoperoxidase activity was visualised with $3,3^{\prime}-$ diaminobenzidene tetrahydrochloride $(0.5 \mathrm{mg} / \mathrm{ml})$ in TBS+0.03\% (v/v) hydrogen peroxide in which the sections were incubated for $5 \mathrm{~min}$. Following a final wash of $5 \mathrm{~min}$ in TBS, the sections were counterstained in Gill's haematoxylin, dehydrated through graded alcohols and xylene and finally mounted under coverslips using DePeX mounting medium.

The absence of non-specific staining was determined by the replacement of clone R1 with non-immune mouse ascites fluid. 


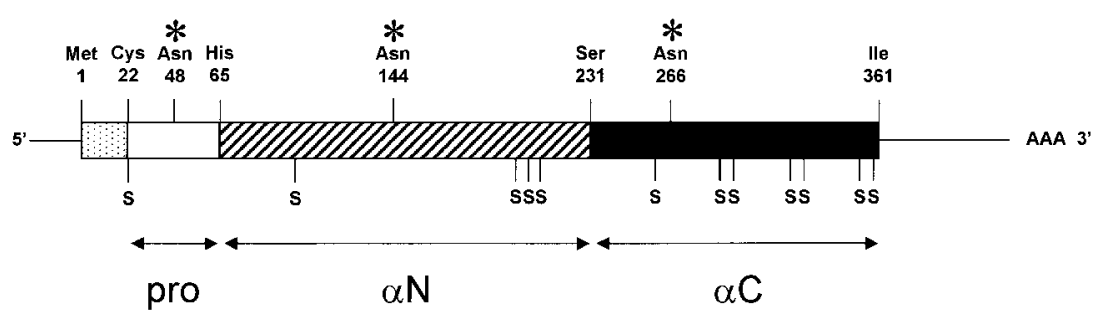

FIGURE 2. Schematic presentation of the possum inhibin $\alpha$-subunit precursor. Coding sequences are boxed, and untranslated sequences are represented by a line. The dotted box represents the coding region for the signal petide. The numbers refer to the amino acid residues. The position of cysteine residues (S) and potential $\mathrm{N}$-linked glycosylation sites (*) are indicated. $\alpha \mathrm{C}, \mathrm{C}$-terminal fragment of $\alpha$-inhibin; $\alpha \mathrm{N}, \mathrm{N}$-terminal fragment of $\alpha$-inhibin; pro, pro-fragment of $\alpha$-inhibin.

\section{RESULTS}

\section{Sequence analysis}

The possum inhibin $\alpha$-subunit cDNA nucleotide and corresponding predicted amino acid sequences are shown in Fig. 1. The cDNA sequence, including the polyA tail, is 1377 nucleotides in length and includes a 1086-nucleotide open reading frame (nucleotides 67-1152) encoding a 361-amino acid precursor protein with a predicted molecular mass of $38.9 \mathrm{kDa}$. The cDNA sequence contains a $3^{\prime}$ untranslated region of 225 bases, which includes a typical polyadenylation signal (5'-AATAAA- $\left.3^{\prime}\right)$ located 15 bases before the polyA tail.

Using homologies with eutherian inhibin $\alpha$-subunits, the proposed site of signal peptide cleavage was assigned between $\mathrm{Gly}^{21}$ and $\mathrm{Cys}^{22}$ (Forage et al. 1986, Mayo et al. 1986, Yamanouchi et al. 1995) and three evolutionary conserved proteolytic processing sites were identified at $\mathrm{Arg}^{63}-\mathrm{Arg}^{64}, \mathrm{Arg}^{73}-\mathrm{Arg}^{74}$ and $\mathrm{Arg}^{229}-\operatorname{Arg}^{230}$ (Figs $1,3)$. By analogy with the processing of eutherian homologues, the $\alpha \mathrm{N}-\alpha \mathrm{C}$ fragment (amino acids 65-361) is predicted to be derived from the full-length precursor by cleavage at the C-terminal site to the dibasic motif, $\operatorname{Arg}^{63}-\operatorname{Arg}^{64}$ (Fig. 2) and further proteolytic processing at $\mathrm{Arg}^{229}-\mathrm{Arg}^{230}$ generates two fragments of $166(\alpha \mathrm{N} ; 65-230)$ and $131(\alpha \mathrm{C} ; 231-361)$ amino acids (Fig. 2). The mature $\alpha$-chain is the 131 -amino acid $\alpha \mathrm{C}$ fragment, leading to a calculated molecular mass of $14 \cdot 2 \mathrm{kDa}$. Three potential N-linked glycosylation sites (Asn-X-Thr/ Ser; Pless \& Lennarz 1977) were found in the predicted $\alpha$-inhibin protein sequence $\left(\mathrm{Asn}^{48}, \mathrm{Asn}^{144}\right.$ and $\left.\mathrm{Asn}^{266}\right)$. There are 12 evolutionarily conserved cysteine residues in the precursor $\alpha$-subunit: one at $\mathrm{Cys}^{22}$, four in the $\alpha \mathrm{N}$ fragment $(96,198,201,203)$ and seven in the $\alpha \mathrm{C}$ fragment $(260,289,293,322$, 323, 358, 360) (Figs 1, 3).
The deduced amino acid sequence of the possum inhibin $\alpha$-subunit precursor protein was aligned with six eutherian homologous sequences (Fig. 3). Quantitative comparisons between the sequences revealed mean identities of $71.8 \%$ (coding region nucleotide sequence), $69 \cdot 8 \%$ (deduced amino acid sequence of full-length precursor protein), $70 \cdot 5 \%$ (deduced amino acid sequence of 'pro' fragment), $65.8 \%$ (deduced amino acid sequence of $\alpha \mathrm{N}$ fragment) and $79 \cdot 7 \%$ (deduced amino acid sequence of $\alpha \mathrm{C}$ fragment).

\section{Gene expression in adult ovary}

Northern hybridisation using a possum inhibin $\alpha$-subunit cDNA probe detected a transcript of approximately $1.6 \mathrm{~kb}$ in possum ovarian RNA with no hybridising transcript detected in possum liver RNA (negative control) (Fig. 4).

The cell-type distribution of $\alpha$-inhibin gene expression within the ovary was investigated by RNA in situ hybridisation. The inhibin $\alpha$-subunit RNA probe hybridised specifically to the granulosa cell layers of follicles, whereas no expression was detected in the theca cell layers or in the ovarian stroma (Fig. 5B, D, F). The $\alpha$-inhibin gene expression was examined in the granulosa cells of follicles at different stages of development. No $\alpha$-inhibin mRNA was detected in primordial follicles containing only one layer of flattened granulosa cells (Fig. 5B, D). Expression of $\alpha$-inhibin was observed in primary follicles (those in which one to two layers of cuboidal granulosa cells were forming; Fig. 5D) and in all subsequent stages of follicular development (Fig. 5B). In large antral follicles, expression was evident in the cumulus granulosa cells surrounding the oocyte, but not in the oocyte itself (Fig. 5F). Finally, $\alpha$-inhibin gene expression was detected in corpus luteum (Fig. 5H). 


\begin{tabular}{|c|c|c|c|c|c|}
\hline & 1 & & $\bullet$ & & $\star 50$ \\
\hline possum & MLPLLLPLQL & LLLMVMKGGH & GCQGPELDRE & LVLAKVRALV & LDALGPPNAS \\
\hline equine & MVPP. . I. & . . L. EQ. . & $\ldots$..... & $I \ldots \ldots F$ & $\ldots \ldots$ AVT \\
\hline human & MV.H.L. & E. . LTPQ... & $S \ldots I \ldots A$. & $\ldots \ldots \ldots F$ & . AVT \\
\hline bovine & $M W \cdot Q \cdot-$. & $\ldots$ LAPQ $\ldots$ & . H.L.... & $\ldots \ldots \ldots F$ & $\ldots \ldots$. РVT \\
\hline porcine & MWPQ. - . & ... LAPRS $\ldots$ & $\ldots \ldots \ldots$ & $\ldots \ldots \ldots F$ & $\ldots \ldots$. AVT \\
\hline mouse & MVSQRS.L. & . . . LTLRDVD & $s \ldots . . . v$ & $\ldots \ldots$ K. E & $\ldots \ldots \ldots$ AMD \\
\hline \multirow[t]{2}{*}{ rat } & MVIQPS.I. & . . . LTLQDVD & s...... & $\ldots \ldots$ K. F & $\ldots \ldots$ AMD \\
\hline & 51 & $\nabla$ & $\nabla$ & & - 100 \\
\hline possum & KDGGKPVAQR & ETRRHAHTGG & STRRSMENED & EDLSQVILEP & TTGPGCEDEP \\
\hline equine & GE. . D.GVR. & . P...-I. & FA..GS.P.E & .V.A... & AS.SR. . . . \\
\hline human & RE . D.GVR. &. P...LLG.F & TH.G.EPE.E & .V. . . . . & A.DAS...KS \\
\hline bovine & GE. .D.GVR. & $. \mathrm{H} \ldots-\mathrm{V} \ldots$ & FM..GS.P. & Q.V.A... & AA.AS.G... \\
\hline porcine & GE. .D.GVR, & . P . . - V . . & FM. .GS.P.E & .V.A. . & A. .AR.G... \\
\hline mouse & GE. .D.GIR. & $. P \ldots-V \ldots$ & FMH.TS.P.E & $\ldots$ V. . . . & A. AT . . Q . \\
\hline \multirow[t]{2}{*}{ rat } & GE. .G.GIR. & 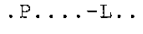 & FMH.TS.P.E & $\ldots V \ldots A \ldots$ & $\mathrm{A} . . \mathrm{AT} \ldots \mathrm{QA}$ \\
\hline & 101 & & & & * \\
\hline possum & EAR-----AA & EGLETYTERP & SLHTRSRQVT & AAQLWEHTGL & DKVGAEVHND \\
\hline equine & A. GELAQE. E & Q....M... & $. Q . M \ldots$ & S.H.. & . RQ.TAAS.S \\
\hline human & A. . GLAQE.E & $\ldots$ R.M. &.$Q \ldots \ldots$ & $s \ldots \ldots$ & .RQ.TAAS.S \\
\hline bovine & D. GE $\cdots . E$ & \# WV.Q. & $.0 \ldots$ & $s \ldots \ldots$ & .RQETAAA.S \\
\hline porcine & A. GELARE.E & $\ldots \ldots v \ldots$ & . Q. H. & $\ldots$ & .RQ.MAAA.S \\
\hline mouse & A. GLAQE.E & $\ldots \ldots v \ldots$ & .Q.I..H... & S.. & GRKSTAAA.S \\
\hline \multirow[t]{2}{*}{ rat } & A. GGLAQEPE & $\ldots \ldots v \ldots$ & .Q.I.H... & $\cdots$ & . RKSTAAS.S \\
\hline & 151 & & & & 200 \\
\hline possum & SGPMVTLLAM & SSGGPMAVPI & LLGPAPPHWA & VLHLAAEAET & LLTRPLLVLL \\
\hline equine & . E.LLG . . . L & $\ldots \ldots \ldots v$ & T. . . . . . & . . . S.LS.LF & ..н.V... \\
\hline human & . E. LLG . . L &.$P \ldots V \ldots M$ & S..H.... & ....TS.LS & . . H.V... \\
\hline bovine & . E.LLG . .VL & T...P. & S.Q..R. & ...TS.P & . .H.V.A. \\
\hline porcine & $\ldots$. LLD . . . L & $\ldots R \ldots V \ldots M$ & S..Q...R. & .....S.LF & ..H.V... \\
\hline mouse & . A. LLD . . VL & $\ldots \ldots \ldots v$ & S.VQG..R. . & $\ldots . .$. S. P & ..H.I... \\
\hline \multirow[t]{2}{*}{ rat } & , R.LLD . . VL & $\ldots \ldots \ldots v$ & S..QS..R. & $\ldots \ldots$. & ..H.I... \\
\hline & - $\bullet$ & & & $\nabla$ & 250 \\
\hline possum & LRCPNCPCPA & QLDATEFLVA & HTRARPPSVG & ERARRSPLPP & BWPWSPAATR \\
\hline equine & ...LIS.S. & RPE . . . . . & $\ldots \ldots \ldots$ & .T..TP.L & $\ldots \ldots \ldots$ \\
\hline human & ...L.T.S. & RPE $\ldots \ldots$ & $\ldots \mathrm{T}$ & $\ldots \ldots$ TPEM & $s \ldots$ s... \\
\hline bovine & ....L.S.ST & RPE... & ...K...G. & ......TP.L & $\ldots \ldots$ \\
\hline porcine & ...L.S.S. & RPE . . & $\ldots \ldots \ldots$, & $\ldots \ldots$ TA.L & $\ldots \ldots \ldots$ \\
\hline mouse & ....L.S.SG & RPET . & ...A. A. & . . . . . TPSV & $\ldots \ldots \ldots$ \\
\hline \multirow[t]{2}{*}{ rat } & ....L.S.SG & RPET . . . . & $\ldots$. . . & $\ldots \ldots$ APSM & $\ldots \ldots \ldots$ \\
\hline & 251 & - & $\star$ & & $\bullet$ \\
\hline possum & LLQRPSEDPA & AHADCHRAAL & NISFQELGWD & QWIVHPRSFI & FHYCHGGCGL \\
\hline equine & ,..P.E. & $\ldots$ N. . . . & $\ldots \ldots \ldots$ & R....R. . & $\ldots \ldots \ldots$ \\
\hline humar & ...P.E. & ..N...V. & $\ldots \ldots \ldots$ & R...Y... & $\ldots \ldots \ldots$ \\
\hline bovine & W Р.Р. Е & $\ldots \ldots \ldots$ & $\ldots \ldots \ldots$ & $R \ldots \ldots \ldots$ &.$Y \ldots \ldots$ \\
\hline porcine & \#.P.E. & $v \ldots \ldots s$. & $\cdots$ & $R \ldots \ldots \ldots$ & $\ldots \ldots \ldots$ \\
\hline mouse & ...P.E. & $\ldots F \ldots \ldots$ & $\ldots \ldots$ & $R \ldots \ldots \ldots$ & $\ldots \ldots s \ldots M$ \\
\hline \multirow[t]{2}{*}{ rat } & ...P.E.S & $\ldots F \ldots \ldots$ & $\ldots \ldots \ldots$ & R....... & $\ldots \ldots S \ldots M$ \\
\hline & 301 & & - & - & 350 \\
\hline possurn. & VPSPVLS-- - & PGAALTPSQP & LPLGPGSRPC & CAAMPSTMRP & LRVRTTSDGG \\
\hline equine & SAR.D. PLPV & . EVPP. . I. & .S.V. .AQ . & $\ldots I, G \ldots$ & . \\
\hline human & HIP.N. . LPV & $\ldots$ PP . A. & YS.L. .AQ . & ..I.G... &.$H \ldots \ldots$ \\
\hline bovine & S. PQD. PLPV & $\ldots$ VPP . V $\ldots$ & .S.V. .AQ. & ..I.G... &.$H \ldots \ldots$ \\
\hline porcine & PTL.N.PISVV & $\ldots$ PP..V. & . L.V. AQ. . & $\ldots$ I.G...S & $\ldots \ldots \ldots$ \\
\hline mouse & PT.DL-PLPV & . VPP . V. . & . F, V. AKK. & ...I.GS.TS & $\ldots \ldots \ldots$ \\
\hline \multirow[t]{2}{*}{ rat } & PT.DL-PLPV & ..PP.A. & .F.V.AAK. & ...L.GS..S & $\ldots \ldots \ldots$ \\
\hline & 351 & $\bullet$ & & & \\
\hline possum & YSFKYE IVFN & LLTQHCACI & 361 & & \\
\hline equine & $\ldots \ldots \ldots$ & $\ldots \ldots \ldots$ & 367 & & \\
\hline human & $\ldots \mathrm{T}$. & $\ldots$ & 366 & & \\
\hline bovine & $\ldots \ldots M_{2} \ldots$ & $\ldots \ldots \ldots$ & 360 & & \\
\hline porcine & $\ldots \ldots$ T. & $\ldots \ldots \ldots$ & 364 & & \\
\hline mouse & $\ldots \ldots$ M... &.$I \ldots \ldots$ & 366 & & \\
\hline rat & $\ldots \ldots M_{\ldots}$ & $I \ldots \ldots$ & 366 & & \\
\hline
\end{tabular}

FIGURE 3. Comparison of the deduced amino acid sequence of possum inhibin $\alpha$-subunit precursor protein with six eutherian mammal homologues (equine (Yamanouchi et al. 1995), human (Mayo et al. 1986), bovine (Forage et al. 1986), porcine (Mason et al. 1985), mouse (Albano et al. 1993) and rat (Woodruff et al. 1987)).

The sequences are aligned to show maximum homology. Positions at which sequences are identical with that of the possum are indicated by dots. Space insertions are indicated by - . The positions of conserved cysteine residues $(\mathbf{O})$, potential N-linked glycosylation sites (*) and proteolytic cleavage sites $(\boldsymbol{\nabla})$ are indicated. The length for each protein sequence is given at the end of each sequence. 


\section{Li Ov}

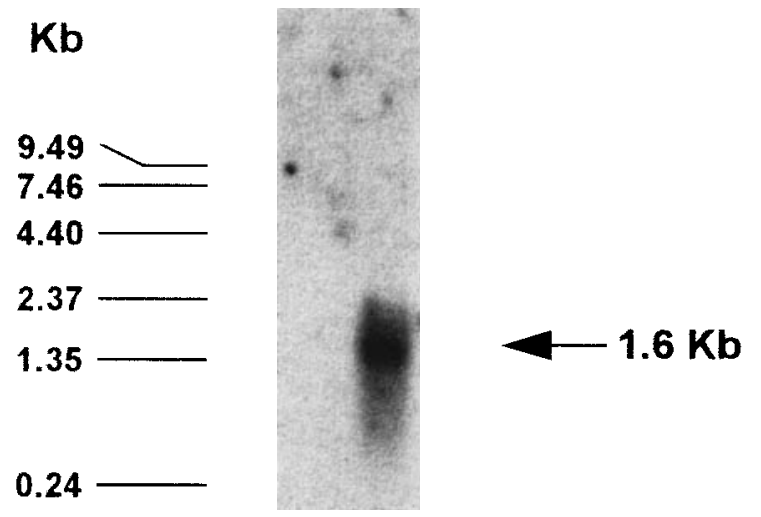

FIGURE 4. Northern blot analysis of total RNA extracted from possum liver (lane 1) and ovary (lane 2) hybridised with a possum inhibin $\alpha$-subunit probe. The positions of molecular weight standards are indicated. $\mathrm{Kb}=$ kilobase.

No hybridisation above random background was observed using the sense control probe (data not shown).

\section{Protein localisation in adult ovary}

The immunocytochemical localisation of inhibin $\alpha$-subunit in adult possum is shown in Fig. 6 . Inhibin $\alpha$-subunit protein was localised to granulosa cells of developing follicles, whereas no immunostaining was detected in the theca cell layer or in the ovarian stroma (Fig. 6A). Immunostaining for the inhibin $\alpha$-subunit was first observed in granulosa cells of primary follicles and this staining was evident throughout folliculogenesis (Fig. 6A, B). $\alpha$-Inhibin protein was also detected in cells of the corpus luteum (Fig. 6C).

\section{DISCUSSION}

This paper reports the cDNA sequence and pattern of expression of the inhibin $\alpha$-subunit gene of the brushtail possum. Comparison of the predicted amino acid sequence with those of six eutherian homologues gives a mean sequence identity for the mature protein of $79.7 \%$, which is lower than the mean homology observed between the eutherian $\alpha$-inhibin sequences $(87 \cdot 5 \%)$. This is not unexpected, given the 130 million years separating the evolution of the marsupial and eutherian lineages (Janke et al. 1997).
It seems that the major functional groups of the amino acid sequence have been conserved during evolution: the positions of proteolytic cleavage processing sites, N-linked glycosylation sites and the number and positions of cysteine residues. It is known that, in eutherians, inhibin $\alpha$-subunit is synthesized as a precursor protein that is processed by sequential proteolysis, first removing the 20 amino acids signal sequence (Forage et al. 1986, Mayo et al. 1986), and then cleavage at three dibasic sequences producing various forms of different lengths, of which the $\mathrm{C}$-terminal fragment $(\alpha \mathrm{C})$ is considered the mature $\alpha$-subunit (Mason et al. 1985, Mayo et al. 1986, Forage et al. 1986, Woodruff et al. 1987, Albano et al. 1993, Yamanouchi et al. 1995). In the present study, the cDNA sequence for possum predicts a molecular mass of $14 \cdot 2 \mathrm{kDa}$ for the $\alpha \mathrm{C}$ fragment, similar to the calculated molecular mass of the mature $\alpha$-subunit in porcine (Mason et al. 1985), bovine (Forage et al. 1986) and equine (Yamanouchi et al. 1995) species. In possums, there are no data available with respect to the actual molecular masses of the different forms of the inhibin $\alpha$-subunit resulting from proteolytic processing. However, the presence of potential $\mathrm{N}$-linked glycosylation sites indicates that it is likely to be larger than that predicted from the amino acid sequence (Forage et al. 1986). Such glycosylation accounts for the difference in size between that calculated from the amino acid sequence and the empirically measured values of porcine (Mason et al. 1985, Mayo et al. 1986) and bovine $\alpha$-inhibins (Forage et al. 1986). The potential N-linked glycosylation sites are preserved at $\mathrm{Asn}^{144}$ and $\mathrm{Asn}^{266}$ across the different species (Fig. 3). There is, however, an additional potential N-linked glycosylation site in the possum $\alpha$-inhibin sequence at $\mathrm{Asn}^{48}$. The number and distribution of cysteine residues in the amino acid sequences are also evolutionarily conserved between possum and eutherian species. There are four cysteine residues in the $\alpha \mathrm{N}$ fragment amino acid sequence, suggesting possible intrachain disulphide bonds that enable the separation of the $\alpha \mathrm{N}$ fragment from the $\alpha \mathrm{C}$ fragment (Wang \& Johnson 1993). The odd number (seven) of cysteine residues in the $\alpha \mathrm{C}$ fragment suggests that at least one may be free to form a disulphide bond with the inhibin $\beta$-subunit during heterodimer formation (Wang \& Johnson 1993).

The $\alpha \mathrm{C}$ fragment of possum $\alpha$-inhibin shows $79 \cdot 7 \%$ amino acid identity with the six eutherian $\alpha$-inhibin sequences reported. This is greater than the identity for the full-length precursor protein $(69 \cdot 8 \%)$ and for the $\alpha \mathrm{N}-\alpha \mathrm{C}$ fragment $(71 \cdot 2 \%)$. The comparatively high level of sequence conservation 

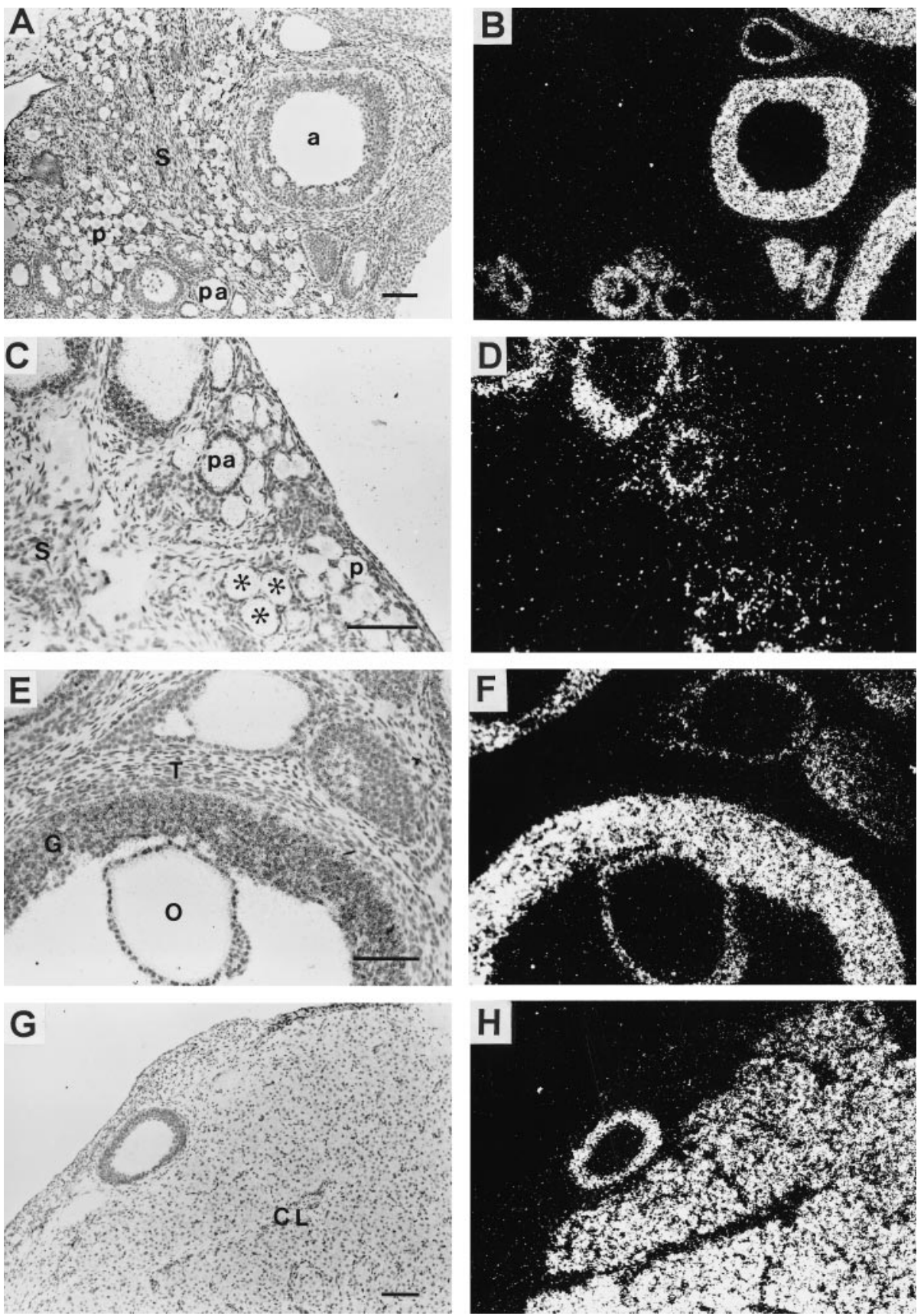

FIGURE 5. Localisation of $\alpha$-inhibin mRNA in adult possum ovary using in situ hybridisation. Left, bright-field photomicrographs stained with haematoxylin; right, corresponding dark-field photomicrographs. (A, B) Hybridisation of the $\alpha$-inhibin antisense riboprobe to the granulosa cells of preantral and antral follicles. No hybridisation is evident in the granulosa cells of primordial follicles or in the stroma. (C, D) Hybridisation of the $\alpha$-inhibin antisense riboprobe to the primary follicle with one layer of granulosa cells (asterisk). No hybridisation is evident in the granulosa cells of primordial follicles. (E, F) Hybridisation of the $\alpha$-inhibin antisense riboprobe to the granulosa cells and cells of the cumulus oophorus but not to the thecal cells and oocyte of an antral follicle.

$(\mathrm{G}, \mathrm{H})$ Hybridisation of the $\alpha$-inhibin antisense riboprobe to cells of the corpus luteum. a, antral follicle; CL, corpus luteum; G, granulosa cells; O, oocyte; p, primordial follicle; pa, preantral follicle; S, stroma; T, thecal cells. Scale bars represent $100 \mu \mathrm{m}$. 

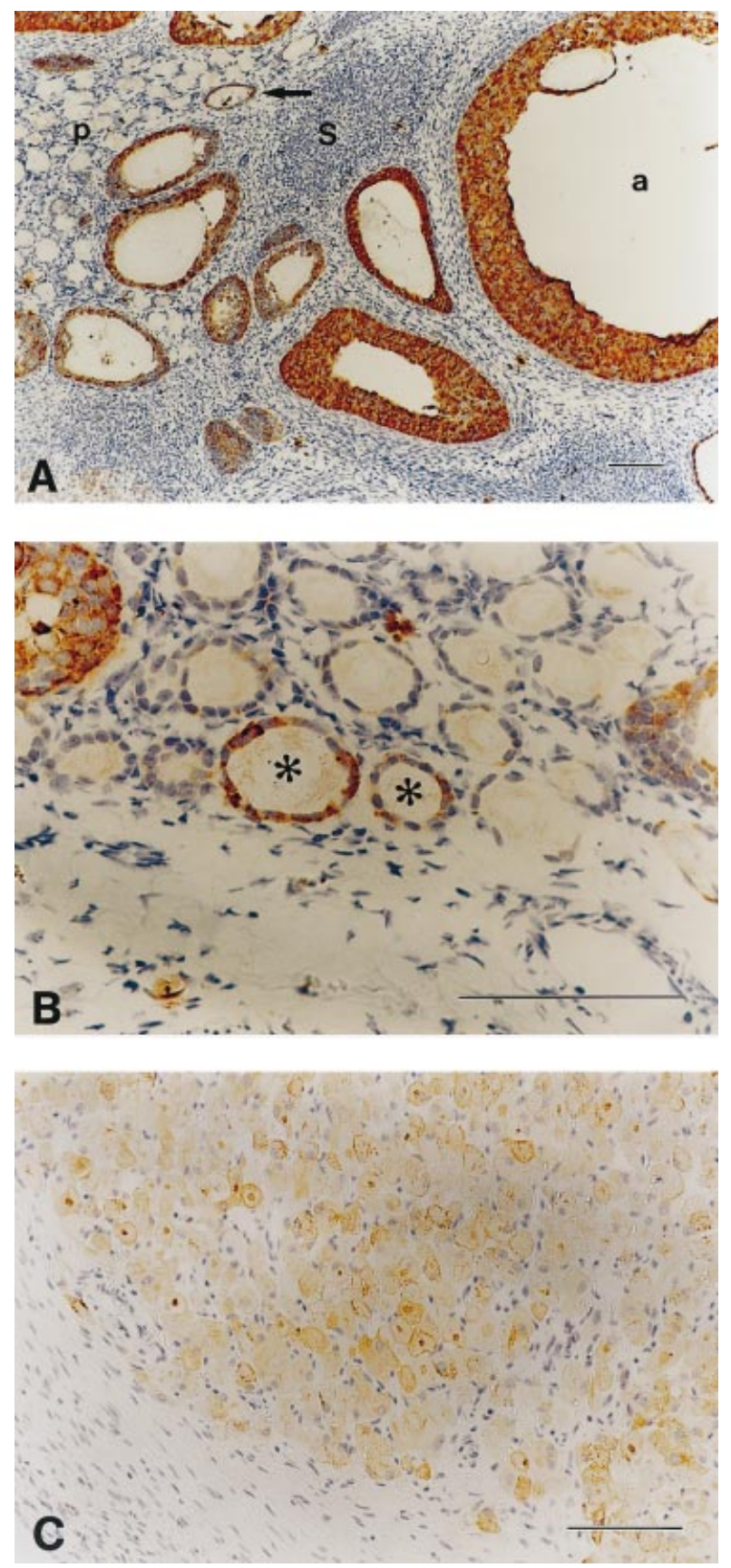

FIGURE 6. Photomicrographs showing immunocytochemical localisation of inhibin $\alpha$-subunit in adult possum ovary. (A) Immunostaining in the granulosa cells of preantral (arrow) and antral follicles. No immunostaining is evident in the granulosa cells of primordial follicles or in the stroma.

(B) Immunostaining in the granulosa cells of primary follicles (asterisk). (C) Immunostaining in cells of the corpus luteum. a, antral follicle; $\mathrm{p}$, primordial follicle; $\mathrm{S}$, stroma. Scale bars represent $100 \mu \mathrm{m}$. of the $\alpha \mathrm{C}$ fragment might indicate that it is the dominant form of the different cleavage products, which forms in combination with a $\beta$-subunit biologically active inhibin. Furthermore, the greater conservation of the 'pro' fragment $(70 \cdot 5 \%)$ compared with the $\alpha \mathrm{N}$ fragment $(65 \cdot 8 \%)$ might be of importance, as it forms, in combination with the $\alpha \mathrm{C}$ fragment, the protein, pro- $\alpha \mathrm{C}$, the latter being an $\alpha$-subunit product that has been isolated from follicular fluid and serum (Knight et al. 1989, Schneyer et al. 1990). Recently, Groome et al. (1995) raised the possibility that pro- $\alpha \mathrm{C}$ and other precursor forms of the $\alpha$-subunit may themselves be functional.

Northern hybridisation revealed that the possum inhibin $\alpha$-subunit gene is expressed in ovary as a transcript of approximately $1.6 \mathrm{~kb}$ which is similar to that reported for the inhibin $\alpha$-subunit of pig (Mason et al. 1985), rat (Woodruff et al. 1987), sheep (Fleming et al. 1992) and horse (Yamanouchi et al. 1995).

In situ hybridisation and immunocytochemistry localised inhibin $\alpha$-subunit to the granulosa cells of the developing follicle. These data are in accordance with the findings of previous immunohistochemical (Merchenthaler et al. 1987), in situ hybridisation (Woodruff et al. 1988, Torney et al. 1989, Jih et al. 1993, Tisdall et al. 1994, Engelhardt et al. 1995, Braw-Tal 1994), in vitro (Erickson \& Hsueh 1978, Henderson \& Franchimont 1981) and physiological (McNatty et al. 1993) studies in eutherian mammals. In addition to the expression of $\alpha$-inhibin in granulosa cells, there have been reports of $\alpha$-inhibin expression in the thecal cell layer in cattle (Torney et al. 1989) and in thecal and stromal cells in the rat ovary (Meunier et al. 1988, Jih et al. 1993). In this study, no evidence of $\alpha$-inhibin mRNA or protein was found in the thecal or stromal cells of the possum ovary. Hybridisation and immunostaining for the inhibin $\alpha$-subunit were first observed in granulosa cells of primary follicles and also in granulosa cells at subsequent stages of follicular growth. It appears that $\alpha$-inhibin expression is switched on in follicles after the transition from flattened to cuboidal granulosa cells. To our knowledge, this is the first time that $\alpha$-inhibin expression has been reported at such an early stage of folliculogenesis. In previous studies of eutherian mammals, $\alpha$-inhibin expression was first observed in follicles in the late preantral stage (Woodruff et al. 1987, Meunier et al. 1988, Braw-Tal 1994) or the antral stage (Woodruff et al. 1988, Torney et al. 1989, Tisdall et al. 1994). The increased levels of $\alpha$-inhibin mRNA and protein (shown by the increasing number of silver grains and the intensity of immunostaining) with increasing follicular 
diameter in the adult possum support previous correlations between follicle size or granulosa cell number and follicular $\alpha$-inhibin expression (Torney et al. 1989, Guthrie et al. 1992, Li et al. 1997) or inhibin content (Tsonis et al. 1983, Hillier et al. 1989, Campbell et al. 1991, McNatty et al. 1993) in eutherian mammals. As expression is associated with antrum formation and the highest level of gene expression is found in estrogenic follicles selected to ovulate, the main role may be to limit the number of less mature follicles that ovulate (Guthrie et al. 1992). The present data suggest that, in marsupials, inhibin may, besides limiting the maturation of ovulatory follicles, have an additional role in the early stages of ovarian follicle development.

Inhibin $\alpha$-subunit mRNA and protein were also detected in the corpus luteum. This is in accordance with the findings of previous studies in rat (Davis et al. 1987, Woodruff et al. 1987, Cuevas et al. 1987, Merchenthaler et al. 1987) and human (Davis et al. 1986) luteal cells. In contrast, Woodruff et al. (1988) failed to detect any $\alpha$-inhibin subunit mRNA in rat luteal cells. Furthermore, there was no evidence of $\alpha$-inhibin subunit expression in the corpus luteum in sheep (Fleming et al. 1992, Tisdall et al. 1994, Rodgers et al. 1989) and cattle (Rodgers et al. 1989, Torney et al. 1989). Collectively, these data indicate that inhibin production by the corpus luteum may be species specific.

In eutherians, there is a more widespread distribution of inhibin $\alpha$-subunit than of inhibin BA-subunit (Torney et al. 1989). It has been reported in different species that all follicles expressing inhibin $\beta \mathrm{A}$-subunit also expressed inhibin $\alpha$-subunit, but that there were follicles which expressed inhibin $\alpha$-subunit but in which inhibin $\beta \mathrm{A}$ was not found (Torney et al. 1989, Jih et al. 1993, Braw-Tal 1994, Engelhardt et al. 1995). Braw-Tal (1994) concluded that these smaller follicles are producing a considerable amount of free inhibin $\alpha$-subunit, which is not able to suppress FSH release, but may have an important paracrine/autocrine role in follicular development. The presence of $\alpha$-inhibin mRNA and protein in follicles from the primary stage of follicular growth in the adult possum ovary may point to a similar paracrine/autocrine role for inhibin $\alpha$-subunit in small follicles during folliculogenesis in marsupials.

In conclusion, these results indicate considerable conservation of the structure and possible function of the inhibin $\alpha$-subunit protein since the divergence of the marsupial and eutherian mammalian lineages. The expression data suggest that, in the adult possum, inhibin may have a role in ovarian follicular growth from the primary stage of development.

\section{ACKNOWLEDGEMENTS}

The authors thank Dr D Eckery and L Colbourne for tissue collection. Thanks to A Barkus for assistance with figure preparation and to L Still and L O'Donovan for the preparation of histological sections. This work was financially supported by the New Zealand Ministry of Agriculture (Policy Division).

\section{REFERENCES}

Albano RM, Groome N \& Smith JC 1993 Activins are expressed in preimplantation mouse embryos and in ES and EC cells and are regulated on their differentiation. Development 117 711-723.

Braw-Tal R 1994 Expression of mRNA for follistatin and inhibin/activin subunits during follicular growth and atresia. Fournal of Molecular Endocrinology 13 253-264.

Campbell BK, McNeilly AS, Mann GE \& Baird DT 1991 The effect of stage of estrous cycle and follicular maturation on ovarian inhibin production in sheep. Biology of Reproduction 44 483-490.

Church GM \& Gilbert W 1984 Genomic sequencing. Proceedings of the National Academy of Sciences of the USA 81 1991-1995.

Cuevas P, Ying SY, Ling N, Ueno N, Esch F \& Guillemin R 1987 Immunohistochemical detection of inhibin in the gonad. Biochemical and Biophysical Research Communications 142 23-30.

Davis SR, Dench F, Nikolaidis I, Clements JA, Forage RG, Krozowski $Z$ \& Burger HG 1986 Inhibin $\alpha$-subunit gene expression in the ovaries of immature female rats is stimulated by pregnant mare serum gonadotrophin. Biochemical and Biophysical Research Communications 138 1191-1202.

Davis SR, Krozowski Z, McLachlan RI \& Burger HG 1987 Inhibin gene expression in the human corpus luteum. Fournal of Endocrinology 115 R21-R23.

Engelhardt H, Harkness LM, Thomas GB, Brooks N, McNeilly AS \& Baird DT 1995 Expression of inhibin $\alpha$ - and $\beta_{\mathrm{A}}$-subunit mRNA and protein in the fetal sheep ovary throughout gestation. Molecular and Cellular Endocrinology 107 141-147.

Erickson GF \& Hsueh AJW 1978 Secretion of inhibin by rat granulosa cells in vitro. Endocrinology 103 1960-1963.

Esch FS, Shimasaki S, Cooksey K, Mercado M, Mason AJ, Ying S-Y, Ueno N \& Ling N 1987 Complementary deoxyribonucleic acid (cDNA) cloning and DNA sequence analysis of rat ovarian inhibins. Molecular Endocrinology $\mathbf{1}$ 388-396.

Findlay JK 1993 An update on the roles of inhibin, activin and follistatin as local regulators of folliculogenesis. Biology of Reproduction 48 15-23.

Fleming JS, Tisdall DJ, Greenwood PJ, Hudson NL, Heath DA \& McNatty KP 1992 Expression of the genes for $\alpha$ inhibin, $\beta \mathrm{A}$ inhibin and follistatin in the ovaries of Booroola ewes which were homozygotes or non-carriers of the 
fecundity gene $\mathrm{Fec}^{\mathrm{B}}$. Fournal of Molecular Endocrinology 8 256-273

Forage RG, Ring JM, Brown RW, McInerney BV, Cobon GS, Gregson RP, Robertson DM, Morgan FJ, Hearn MTW, Findlay JK, Wettenhall REH, Burger HG \& de Kretser DM 1986 Cloning and sequence analysis of cDNA species coding for the two subunits of inhibin from bovine follicular fluid. Proceedings of the National Academy of Sciences of the USA 83 3091-3095.

Frohman MA, Dush MK \& Martin GR 1988 Rapid amplification of full-length cDNAs from rare transcripts: amplification using a single gene-specific oligonucleotide primer. Proceedings of the National Academy of Sciences of the USA 85 8998-9002.

Groome NP, Illingworth PJ, O’Brien M, Priddle J, Weaver K \& McNeilly AS 1995 Quantification of inhibin pro- $\alpha$ Ccontaining forms in human serum by a new ultrasensitive two-site enzyme-linked immunosorbent assay. Fournal of Clinical Endocrinology and Metabolism 80 2926-2932.

Guthrie HD, Rohan RM, Rexroad CE \& Cooper BS 1992 Changes in concentrations of follicular inhibin $\alpha$ and $\beta_{\mathrm{A}}$ subunit messenger ribonucleic acids and inhibin immunoactivity during preovulatory maturation in the pig. Biology of Reproduction 47 1018-1025.

Hanahan D 1985 Techniques for transformation of E. coli. In DNA Cloning vol I, pp 109-135. Ed DM Glover. Oxford: IRL Press.

Henderson KM \& Franchimont P 1981 Regulation of inhibin production by bovine ovarian cells in vitro. Fournal of Reproduction and Fertility 63 431-442.

Hillier SG, Wickings EJ, Saunders PTK, Dixson AF, Shimasaki S, Swanston IA, Reichert LE \& McNeilly AS 1989 Control of immunoactive inhibin production by primate granulosa cells. Fournal of Endocrinology $\mathbf{1 2 3}$ 65-73.

Janke A, Xu X \& Arnason U 1997 The complete mitochondrial genome of the wallaroo (Macropus robustus) and the phylogenetic relationship among monotremata, marsupialia and eutheria. Proceedings of the National Academy of Sciences of the USA 94 1276-1281.

Jih MH, Lu JKH, Wan Y-JY \& Wu T-C 1993 Inhibin subunit gene expression and distribution in the ovaries of immature, young adult, middle-aged, and old female rats. Endocrinology 132 319-326.

Knight PG, Beard AJ, Wrathall JHM \& Castillo RJ 1989 Evidence that the bovine ovary secretes large amounts of monomeric a subunits and its isolation from bovine follicular fluid. Fournal of Molecular Endocrinology 2 189-200.

Li MD, DePaolo LV \& Ford JJ 1997 Expression of follistatin and inhibin/activin subunit genes in porcine follicles. Biology of Reproduction $\mathbf{5 7}$ 112-118.

Ling N, Ying S-Y, Ueno N, Esch F, Denorary L \& Guillemin R 1985 Isolation and partial characterization of a Mw 32000 protein with inhibin activity from porcine ovarian follicular fluid. Proceedings of the National Academy of Sciences of the USA 82 7217-7221.

Ling N, Ying S-Y, Ueno N, Shimasaki S, Esch F, Hotta M \& Guillemin R 1986 Pituitary FSH is released by a heterodimer of the $\beta$ subunits from the two forms of inhibin. Nature 321 779-782.

McNatty KP, Hudson NL, Heath DA, Shaw L, Blay L, Berry L \& Lun S 1993 Effect of chronic FSH administration on ovarian follicular development, ovulation rate and corpora lutea formation in sheep. Fournal of Endocrinology 138 315-325.

Mason AJ, Hayflick JS, Ling N, Esch F, Ueno N, Ying S-Y, Guillemin R, Niall H \& Seeburg P 1985 Complementary
DNA sequences of ovarian follicular fluid inhibin show precursor structure and homology with transforming growth factor- $\beta$. Nature 318 659-663.

Mayo KE, Cerelli GM, Spiess J, Rivier J, Rosenfeld MG, Evans RM \& Vale W 1986 Inhibin $\alpha$-subunit cDNAs from porcine ovary and human placenta. Proceedings of the National Academy of Sciences of the USA $\mathbf{8 3}$ 5849-5853.

Merchenthaler I, Culler MD, Petruz P \& Negro-Vilar A 1987 Immunocytochemical localization of inhibin in the rat and human reproductive tissues. Molecular and Cellular Endocrinology 54 239-243.

Meunier H, Cajander SB, Roberts VJ, Rivier C, Sawchenko PE, Hsueh AJW \& Vale W 1988 Rapid changes in the expression of inhibin $\alpha-, \beta \mathrm{A}$ - and $\beta \mathrm{B}$-subunits in ovarian cell types during the rat oestrous cycle. Molecular Endocrinology 2 1352-1363.

Miyamoto K, Hasegawa Y, Fukuda M, Nomura M, Igarashi M, Kangawa K \& Matsuo H 1985 Isolation of porcine follicular fluid inhibin of about $32 \mathrm{kDa}$. Biochemical and Biophysical Research Communications 129 396-403.

Pless DD \& Lennarz WJ 1977 Enzymatic conversion of proteins to glycoproteins. Proceedings of the National Academy of Sciences of the USA 74 134-138.

Richards JS, Jahnsen T, Hedlin L, Lifka J, Ratoosh S, Durica JM \& Goldring NB 1986 Ovarian follicular development: from physiology to molecular biology. Recent Progress in Hormone Research 43 231-276.

Robertson DM, Foulds LM, Leversha L, Morgan FJ, Hearn MTW, Berger HG, Wettenhall REH \& de Kretser DM 1985 Isolation of inhibin from bovine follicular fluid. Biochemical and Biophysical Research Communications 126 220-226.

Rodgers RJ, Stuchbery SJ \& Findlay JK 1989 Inhibin mRNAs in ovine and bovine ovarian follicles and corpora lutea throughout the estrous cycle and gestation. Molecular and Cellular Endocrinology 62 95-101.

Schneyer AL, Mason AJ, Burton LE, Zeigner JR \& Crowley WF 1990 Immunoreactive inhibin a-subunit in human serum: implications for radioimmunoassay. Fournal of Clinical Endocrinology and Metabolism 70 1208-1212.

Schwartz NB \& Channing CP 1977 Evidence for ovarian inhibin: suppression of the secondary rise in serum follicle stimulating hormone levels in oestrous rats by injection of porcine follicular fluid. Proceedings of the National Academy of Sciences of the USA 74 5721-5724.

Steinberger E 1971 Hormonal control of mammalian spermatogenesis. Physiological Reviews 51 1-22.

Steinberger A \& Steinberger E 1976 Secretion of an FSH-inhibiting factor by cultured Sertoli cells. Endocrinology 99 918-921.

Tisdall DJ, Hudson N, Smith P \& McNatty KP 1994 Localization of ovine follistatin and $\alpha$ and $\beta_{\mathrm{A}}$ inhibin mRNA in the sheep ovary during the oestrous cycle. Fournal of Molecular Endocrinology 12 181-183.

Torney AH, Hodgson YM, Forage R \& de Kretser DM 1989 Cellular localization of inhibin mRNA in the bovine ovary by in-situ hybridization. Fournal of Reproduction and Fertility 86 391-399.

Tsonis CG, Quigg H, Lee VWK, Leversha L, Trounson AO \& Findlay JK 1983 Inhibin in individual ovine follicles in relation to diameter and atresia. Fournal of Reproduction and Fertility 67 83-90.

Wang SY \& Johnson P 1993 Complementary deoxyribonucleic acid cloning and sequence analysis of the $\alpha$-subunit of inhibin from chicken ovarian granulosa cells. Biology of Reproduction 49 453-458. 
Woodruff TK, Meunier H, Jones PBC, Hsueh AJW \& Mayo KE 1987 Rat inhibin: molecular cloning of $\alpha$ - and $\beta$-subunit complementary deoxyribonucleic acids and expression in the ovary. Molecular Endocrinology 1 561-568.

Woodruff TK, D’Agnostino J, Schwartz NB \& Mayo KE 1988 Dynamic changes in inhibin messenger RNAs in rat ovarian follicles during the reproductive cycle. Science 239 1296-1299.
Yamanouchi K, Yoshida S, Hasegawa T, Ikeda A, Chang K-T, Matsuyama S, Nishihara M, Miyazawa K \& Takahashi M 1995 Molecular cloning of cDNA for inhibin $\alpha$-subunit from equine ovary. Fournal of Veterinary and Medical Science $\mathbf{5 7}$ 905-909.

RECEIVED 2 March 1998 